\title{
A Potential Role of Apelin-13 against Hepatic Injury and Metabolic Disorders in Preeclampsia Induced by L-NAME
}

\author{
Reham Z. Hamza ${ }^{1, *}$, Abdel Aziz A. Diab ${ }^{2}$, Mansour H. Zahra ${ }^{2}$, Mai S. Attia ${ }^{2}$, Suzan M. M. Moursi ${ }^{3}$ \\ and Najah M. Al-Baqami 4 \\ 1 Biology Department, Faculty of Sciences, Taif University, P.O. Box 11099, Taif 21944, Saudi Arabia \\ Zoology Department, Faculty of Science, Zagazig University, Zagazig 44519, Egypt \\ Medical Physiology Department, Faculty of Medicine, Zagazig University, Zagazig 44519, Egypt \\ 4 Department of Biological Sciences, Zoology, King Abdulaziz University, Jeddah 21589, Saudi Arabia \\ * Correspondence: dr_reham_z@yahoo.com or Reham.Z@tu.edu.sa or Reham_z@Zu.edu.eg
}

check for updates

Citation: Hamza, R.Z.; Diab, A.A.A.; Zahra, M.H.; Attia, M.S.; Moursi, S.M.M.; Al-Baqami, N.M. A Potential Role of Apelin-13 against Hepatic Injury and Metabolic Disorders in Preeclampsia Induced by L-NAME. Coatings 2021, 11, 391. https:// doi.org/10.3390/coatings11040391

Academic Editor: El-Sayed Abd El-Aziz

Received: 6 March 2021

Accepted: 26 March 2021

Published: 30 March 2021

Retracted: 16 August 2022

Publisher's Note: MDPI stays neutral with regard to jurisdictional claims in published maps and institutional affil iations.

\section{(c)}

Copyright: (c) 2021 by the authors Licensee MDPI, Basel, Switzerland. This article is an open access article distributed under the terms and conditions of the Creative Commons Attribution (CC BY) license (https:/ / creativecommons.org/licenses/by/ $4.0 /)$.

\begin{abstract}
Background: Hypertensive disorders of pregnancy, gestational hypertension, and preeclampsia (PE) are exceptionally challenging, as their pathologies and therapeutic management simultaneously influence the mother and embryo, sometimes putting their well-beings at odds with each other. Dysregulated lipid and glucose metabolism may be related to some cases of preeclampsia. Fluctuations in serum apelin levels may be attributed to changes in the serum levels of multiple interrelated factors such as insulin, insulin resistance, inflammatory cytokines, and nephritic damage. Previous studies demonstrated that apelin is an endogenous active peptide with vasodilatory and antioxidative-stress capabilities. Objective: We investigated the relationships among hepatic, nephrotic, and metabolic injuries in different preeclampsia-like mouse models and the potential effect of exogenous apelin administration on hepatic and nephrotic injuries and metabolic disorders in an N-nitro-L-arginine methyl ester (L-NAME) preeclampsia-like Sprague Dawley (SD) rat model. Materials and methods: Forty-three adult female and ten adult male SD rats were involved in this study. The male rats were used to induce pregnancy. The female rats were randomly divided into four equal groups: a non-pregnant group, a normal pregnant group, a group treated with L-NAME to induce preeclampsia, and a group treated with L-NAME and apelin. In all the groups, maternal blood was collected on the 21st day of gestation, and serum samples were used for the determination of systolic blood pressure; the serum uric acid, creatinine, nitric oxide (NO), xanthine oxidase, myeloperoxidase, insulin, glucose, cholesterol, triglyceride (TG), aspartate aminotransferase (AST) and alanine aspartate aminotransferase (ALT) levels; and the HOMA-insulin resistance (HOMA-IR). Results: In rats with pre-eclampsia, the systolic blood pressure; the concentrations of serum uric acid, creatinine, nitric oxide (NO), xanthine oxidase, myeloperoxidase, blood glucose, serum cholesterol, triglycerides, AST, and ALT; and the calculated HOMA-IR were significantly increased compared to those in the rats in the other groups. Additionally, apelin treatment significantly improved these parameters in the apelin-treated group. Conclusion: This study examined the potential mechanisms whereby apelin may act as a curative candidate to reduce hepatic injury and inhibit kidney damage and the development of metabolic disorders in an experimental model of preeclampsia.
\end{abstract}

Keywords: preeclampsia; apelin; kidney diseases; hepatic diseases and metabolism

\section{Introduction}

Preeclampsia (PE) is a dangerous and potentially life-threatening disease for both the mother and fetus, so it is very important to improve the standard diagnostic approach with complementary treatment to address this problem and develop future treatment strategies [1].

The cause of preeclampsia remains incompletely clarified due to the heterogeneous nature of the disease [2]. This ailment is difficult for obstetricians, as there are no compelling 
ways to treat or prevent it, and the antenatal considerations include a troublesome harmony between the danger to the woman of continuing the pregnancy and the danger to the infant from preterm birth [3].

Despite the serious health, social, and economic costs of preeclampsia, no treatments are available to prevent, stabilize, or cure the disease. The only treatment is to end pregnancy by delivery of the baby and placenta, which itself is related to dangers associated with premature birth [4].

Liver disorders of PE may be increased liver enzymes, low platelets (HELLP), acute fatty liver, hyperemesis gravidarum, intrahepatic cholestasis, and autoimmune liver [5]. In addition to control the mother's metabolism, adipocytokines have been involved in pregnancy difficulties, including PE [6].

Apelin is a peptide hormone acting on Angiotensin II receptor-like - 1 (APJ) which is expressed in multiple tissues including the liver [7]. Apelin has been recognized as a novel adipocytokine, discharged in significant amounts by adipose tissue in a directed way. In this regard, apelin is upregulated by obesity and hyperinsulinemia in people and mice [8]. Apelin causes endothelium dependent vasorelaxation by setting off the release of $\mathrm{NO}$, and it increases myocardial contractility $[9,10]$. In view of its angiogenic action, apelin discharged by adipocytes is likely to stimulate blood vessel growth, leading to increase growth of adipose tissue [8,11].

The hyperproduction of apelin observed in obesity has been proposed to be an adaptive response that attempts to prevent the onset of obesity related disorders. Thus, research has focused on the potential link of apelin with obesity related insulin resistance [12,13]. APJ mRNA expression was identified in regions of the brain critical for the control of fluid homeostasis, so apelin may play a role in the regulation of water balance [7]. Sörhede Winzell et al. [14] reported that apelin inhibited insulin secretion in pancreatic islets in mice, suggesting a link with glucose homeostasis. A 14-day apelin treatment in mice was shown to regulate adiposity and to increase uncoupling protein expression [15], proposing a role of apelin in energy metabolism. Some studied documented also that apelin has anti-inflammatory effects by decreasing the mRNA level of IL- 6 and TNF- $\alpha$ [16]. It additionally inhibits release of ROS in adipocytes and promotes an expression of antioxidative enzymes [17]. Notably, Zhou et al. [18] found that Fc-apelin greatly reduced macrophage infiltration and liver tissue injury by histology, which is in agreement with the observed reduction of serum ALT.

Therefore, we designed this study to explore the possible effects of apelin-13 (a 13amino-acid oligopeptide that is the ligand for the apelin receptor (also known as the APJ receptor) on renal functions in an L-NAME-induced rat model of preeclampsia and to identify the possible involved mechanisms.

\section{Materials and Methods}

This study was carried out in the Faculty of Medicine, Zagazig University and involved 60 healthy adult albino rats (50 healthy females and 10 adult males for fertilization), which were obtained from the animal house of the Faculty of Veterinary Medicine, Zagazig University. Rats were kept in steel cages under hygienic conditions, fed a commercial diet with free access to water, and kept at room temperature on a $12 \mathrm{~h}$ light/dark cycle. The experimental methodology was conducted in accordance with the guidelines for the care and use of experimental animals and was reviewed and approved by the ZU-IACUC committee (approval number ZU-IACUC/1/F/78/2019).

Induction of pregnancy: The estrous cycles of rats were investigated for 2 consecutive weeks. Unstained vaginal secretions were directly viewed every morning under a light microscope at $40 \times$ magnification, and the phases of the estrus cycle were detected by investigating the vaginal cytology. The estrus phase was determined by increasing the number of cornified or irregular-shaped epithelial cells in the vaginal smear.

Rats in estrous stage were placed with a mature male rat in a separate cage. After mating, female rats were isolated to confirm copulation in the next morning by the presence of 
a copulation plug or sperms in the vaginal smear. The presence of sperms indicates the first day of gestation [19]. Seven rats from the forty did not get pregnant and have been excluded from the study.

Forty three pregnant rats were randomly divided into four groups: Group 1 (normal non pregnant group; $n=10)$ : Rats have been injected with saline solution $(0.5 \mathrm{~mL} / \mathrm{kg}$ body weight) subcutaneously daily. Group 2 (normal pregnant group; $n=10$ ): Rats have been injected subcutaneously with saline as placebo from day 9 to 20 of gestation. Group 3 (PE-induced group; $n=12$ ): Rats were injected subcutaneously with L-NAME (Sigma Aldrich Co., Steinheim, Germany, $75 \mathrm{mg} / \mathrm{kg}$ body weight/day beginning from 9th to 20th day of gestation) [20]. Group 4 (PE -induced group supplemented with apelin; $n=11$ ): L-NAME rats simultaneously injected with apelin-13 (Sigma Aldrich Co., $6 \times 10^{-8}$ mol subcutaneously $/ \mathrm{kg} / \mathrm{twice}$ daily) beginning from 6 th to 20 th day of gestation [21] while the other groups simultaneously received saline.

\subsection{Measurement of Blood Pressure}

Systolic BP was measured on 18th day pregnancy, using noninvasive BP measurement system (BIOPAC system, Inc.; Goleta, CA, USA) [22].

\subsection{Blood Sampling}

Retro-orbital venous plexus blood samples were obtained at 21st day of pregnancy after overnight fasting then serum was separated by allowing the blood samples to clot then centrifuged at $3000 \mathrm{rpm}$ for $20 \mathrm{~min}$, kept at $\left(-20^{\circ} \mathrm{C}\right)$ until used.

\subsection{Serum Analysis}

- Measurement of serum insulin level: was carried out as described by Temple et al. [23] using rat insulin ELISA Kit (from RayBiotech.com (accessed on 29 March 2021)).

- Measurement of serum glucose level: was carried out as described by Tietz et al. [24] using Biodiagnostic kit for colorimetric determination of serum urea concentration (from (Biodiagnositc Company, Dokki, Giza, Egypt).

- Calculation of Homeostatic model assessment for insulin resistance (HOMA-IR): The results of glucose and insulin measurements were introduced into equations to measure the HOMA-IR, as a measure of insulin resistance and beta cell function. Many equations were designed to calculate these indices. In this study the simplest and accurate equation was used HOMA $=$ serum insulin $(\mu \mathrm{U} / \mathrm{mL}) \times[$ serum glucose $(\mathrm{mg} / \mathrm{dL}) / 405]$ [25].

- Measurement of serum cholesterol level: was carried out as described by Varley and Richmond [26] using Biodiagnostic kit for colorimetric determination of serum urea concentration (from (Biodiagnositc Company, Dokki, Giza, Egypt).

- Measurement of serum triglyceride level: was carried out as described by Fossati and Prencipe [27] using Biodiagnostic kit for colorimetric determination of serum urea concentration (from (Biodiagnositc Company, Dokki, Giza, Egypt).

- Measurement of serum AST and ALT levels: was carried out as described using bio Merieux kit (France).

- Measurement of serum creatinine: was carried out as described by Schirmeister et al. [28] using Biodiagnostic kit for colorimetric determination of serum creatinine concentration (Biodiagnositc Company, Dokki, Giza, Egypt).

- Measurement of serum NO: Was estimated as nitrite, a NO metabolite, by monitoring of reduction of $\mathrm{NO}_{3}{ }^{-}$to $\mathrm{NO}_{2}{ }^{-}$by nitrate reductase (sigma), then nitrite levels were measured using the calorimetric Griess Reaction [29].

- Measurement of serum uric acid: was done as showed by Zhao et al. [30], utilizing Biodiagnostic kit for colorimetric determination of serum uric acid concentration (from (Biodiagnositc Company, Dokki, Giza, Egypt). 
- Measurement of serum myeloperoxidase (MPO) and Xanthune oxidase (XO): Kidney myeloperoxidase (MPO) and xanthine oxidase $(\mathrm{XO})$ levels activity were estimated using methods of Suzuki et al. [31] and Litwack et al. [32].

\subsection{Histopathological Examination}

Immediately after collecting blood samples, rats were killed by decapitation after light ether anesthesia. Liver was excised and rinsed in ice-cold normal saline $\left(4^{\circ} \mathrm{C}\right)$ to remove blood cells, blotted and dried with filter paper then tissue portions from kidneys were kept in $10 \%$ buffered formal saline at $4{ }^{\circ} \mathrm{C}$ for at least one week (1ry fixation). After that, the specimens were dehydrated with a series of ascending grade of ethanol from $75-100 \%$. Then, tissues were placed in xylol and embedded in paraffin wax. Cross sections of about 1-2 $\mu \mathrm{m}$ thickness of kidney was processed on slides and stained with Haematoxylin and Eosin ( $\mathrm{H} \& \mathrm{E}$ ) stain to study the general microscopic features by routine light microscope [33]. The slides were examined under a light microscope by an expert pathologist in a blinded fashion.

\subsection{Statistical Analysis}

Data were presented as mean \pm SD. SPSS version 19 (SPSS Inc., Chicago, IL, USA) was used for performing the statistical analysis. Analysis of variance (ANOVA) followed by LSD post hoc test was performed to compare means of the different groups. $p$ value $<0.05$ was considered to be statistically significant for all statistical tests done.

\section{Results}

Table 1 and Figures 1-6 show non-significant differences between groups 1 and 2 in systolic blood pressure; creatinine, uric acid, myeloperoxidase, xanthine oxidase, and insulin concentrations; and HOMA-IR, as well as slightly significant differences between groups 1 and 2 in nitric oxide, glucose, insulin, AST and ALT concentrations.

Table 1. Serum creatinne, uric acid, nitric oxide (NO), Myloperoxidase (MPO) and xanthine oxidase (XO) of the studied groups.

\begin{tabular}{|c|c|c|c|c|}
\hline & $\begin{array}{c}\text { Group } 1 \\
n=10\end{array}$ & $\begin{array}{c}\text { Group } 2 \\
n=10\end{array}$ & $\begin{array}{c}\text { Group } 3 \\
n=12\end{array}$ & $\begin{array}{c}\text { Group } 4 \\
n=11\end{array}$ \\
\hline Creatinine $(\mathrm{mg} / \mathrm{dL})$ & $0.40 \pm 0.01$ & $0.79 \pm 0.10$ & $1.98 \pm 0.20^{\mathrm{a}, \mathrm{b}}$ & $1.00 \pm 0.20^{\mathrm{a}, \mathrm{b}, \mathrm{c}}$ \\
\hline$p$ value of LSD & \multicolumn{2}{|c|}{$p>0.05$} & $p<0.001^{\mathrm{a}, \mathrm{b}}$ & $p<0.001^{\mathrm{a}, \mathrm{b}, \mathrm{c}}$ \\
\hline Uric acid $(\mathrm{mg} / \mathrm{dL})$ & $20.05 \pm 1.58$ & $23.02 \pm 2.02$ & $34.02 \pm 2.02^{\mathrm{a}, \mathrm{b}}$ & $25.03 \pm 2.01^{a, b, c}$ \\
\hline$p$ value of LSD & \multicolumn{2}{|c|}{$p>0.05$} & $p<0.001^{\mathrm{a}, \mathrm{b}}$ & $p<0.001^{\mathrm{a}, \mathrm{b}, \mathrm{c}}$ \\
\hline Nitric oxide (NO) (mg/dl) & $50.03 \pm 2.02$ & $47.02 \pm 2.05^{a}$ & $22.05 \pm 2.58^{\mathrm{a}, \mathrm{b}}$ & $43.02 \pm 1.95^{\mathrm{a}, \mathrm{b}, \mathrm{c}}$ \\
\hline$p$ value of LSD & $p>0.05$ & $p<0.05^{a}$ & $p<0.001^{\mathrm{a}, \mathrm{b}}$ & $p<0.001^{\mathrm{a}, \mathrm{b}, \mathrm{c}}$ \\
\hline Myeloperoxidase (nmol/min/mL) & $14.40 \pm 0.87$ & $45.36 \pm 2.36$ & $35.67 \pm 1.30^{\mathrm{a}, \mathrm{b}}$ & $29.81 \pm 2.25^{a, b, c}$ \\
\hline$p$ value of LSD & \multicolumn{2}{|c|}{$p>0.05$} & $p<0.001^{\mathrm{a}, \mathrm{b}}$ & $p<0.001^{a, b, c}$ \\
\hline Xanthine oxidase $(\mathrm{U} / \mathrm{g})$ & $12.03 \pm 1.03$ & $17.05 \pm 1.69$ & $49.58 \pm 2.02^{\mathrm{a}, \mathrm{b}}$ & $21.02 \pm 1.59^{a, b, c}$ \\
\hline$p$ value of LSD & \multicolumn{2}{|c|}{$p>0.05$} & $p<0.001^{\mathrm{a}, \mathrm{b}}$ & $p<0.001^{\mathrm{a}, \mathrm{b}, \mathrm{c}}$ \\
\hline
\end{tabular}

Data are presented as Mean $\pm \mathrm{SD}$, a: statistically significant VS group 1, ${ }^{\mathrm{b}}$ : significant VS group 2, ${ }^{\mathrm{s}}$ : significant VS group 3.

Rats in group 3 (preeclampsia group) showed significant increases in systolic blood pressure; concentrations of serum creatinine, uric acid, myeloperoxidase, xanthine oxidase, cholesterol, triglycerides, glucose, insulin, AST and ALT; and HOMA-IR and a significant decrease in the serum nitric oxide concentration when compared to both groups 1 and 2 . However, apelin administration in group 4 resulted in significant changes in these parameters when compared to group 3. 


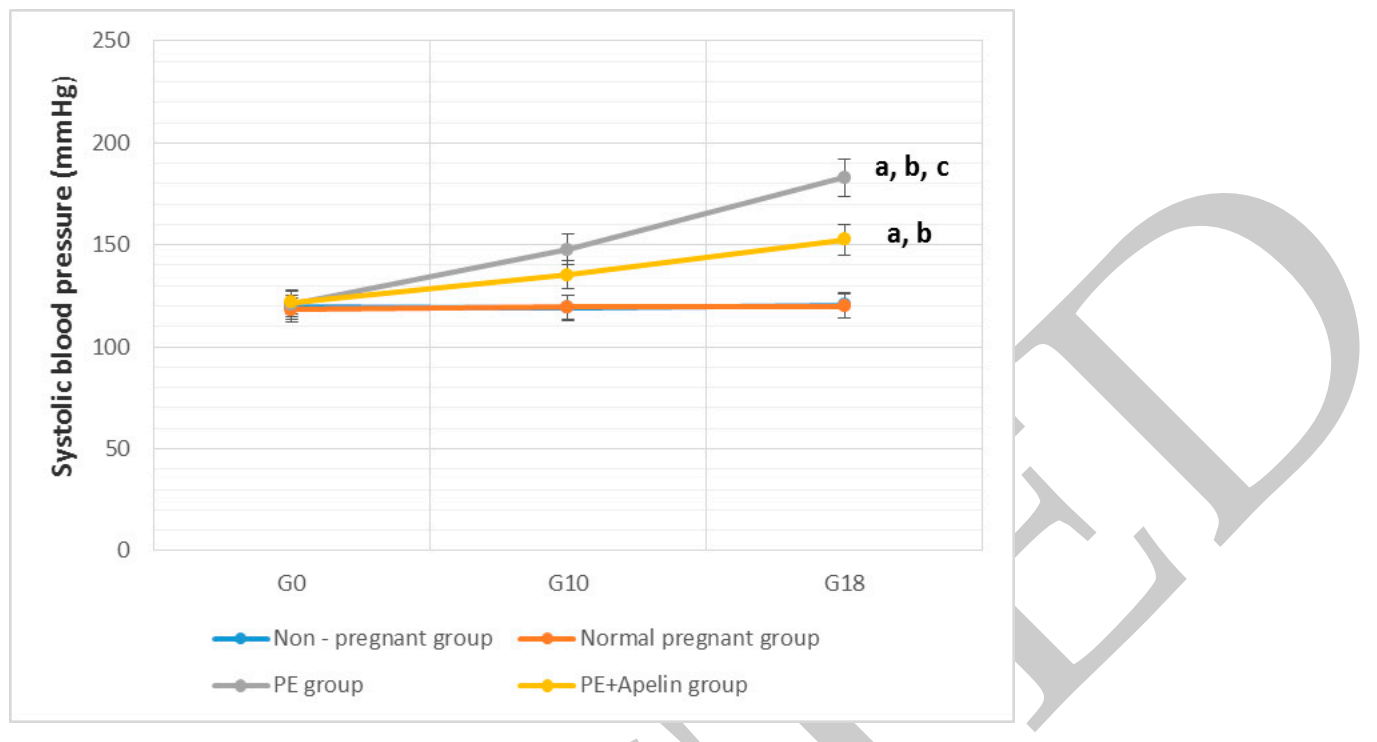

Figure 1. Systolic blood pressure in the studied groups.

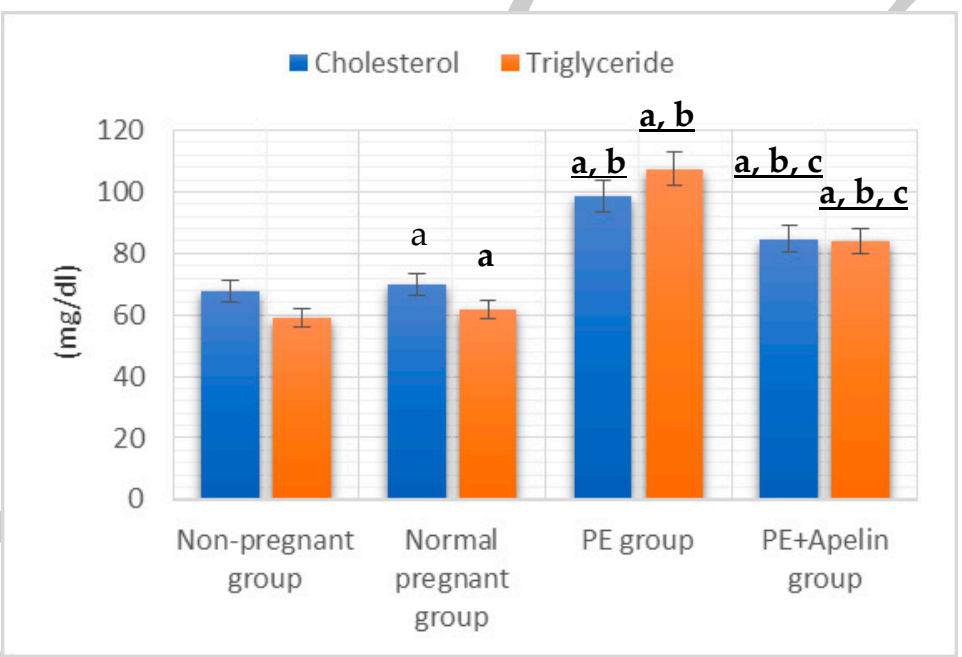

Figure 2. Serum cholesterol and triglyceride in the studied groups.

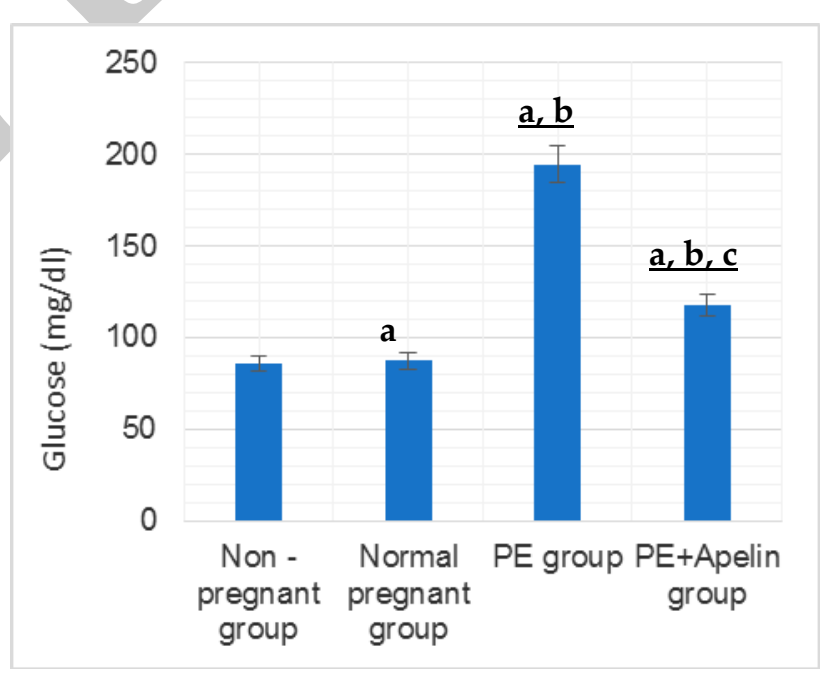

Figure 3. Serum glucose in the studied groups. 


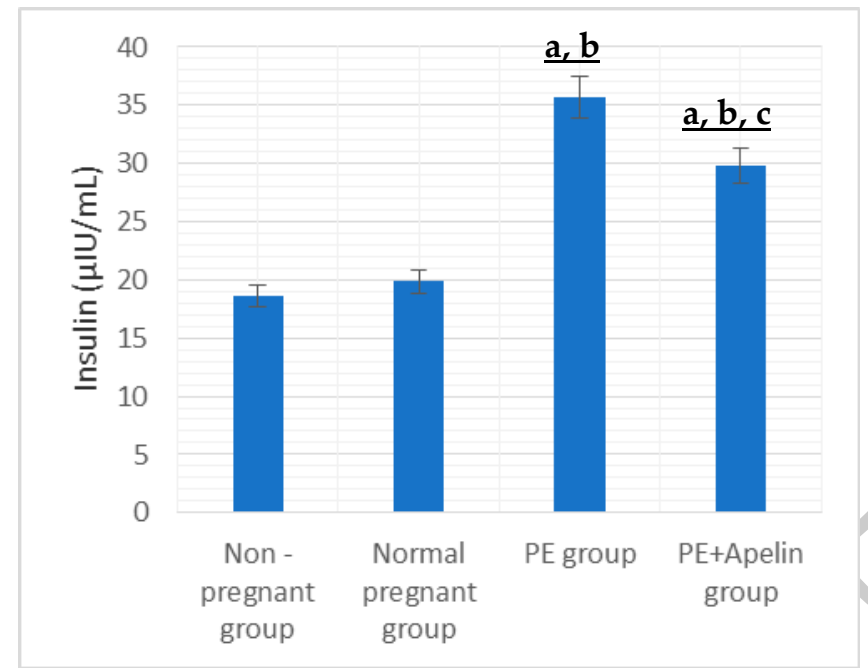

Figure 4. Serum insulin in the studied groups.

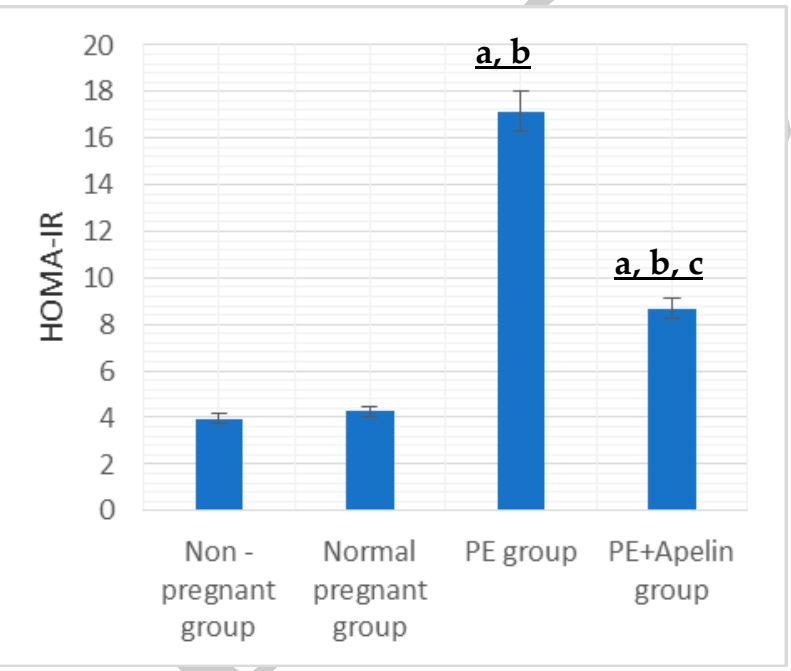

Figure 5. HOMA-IR in the studied groups.

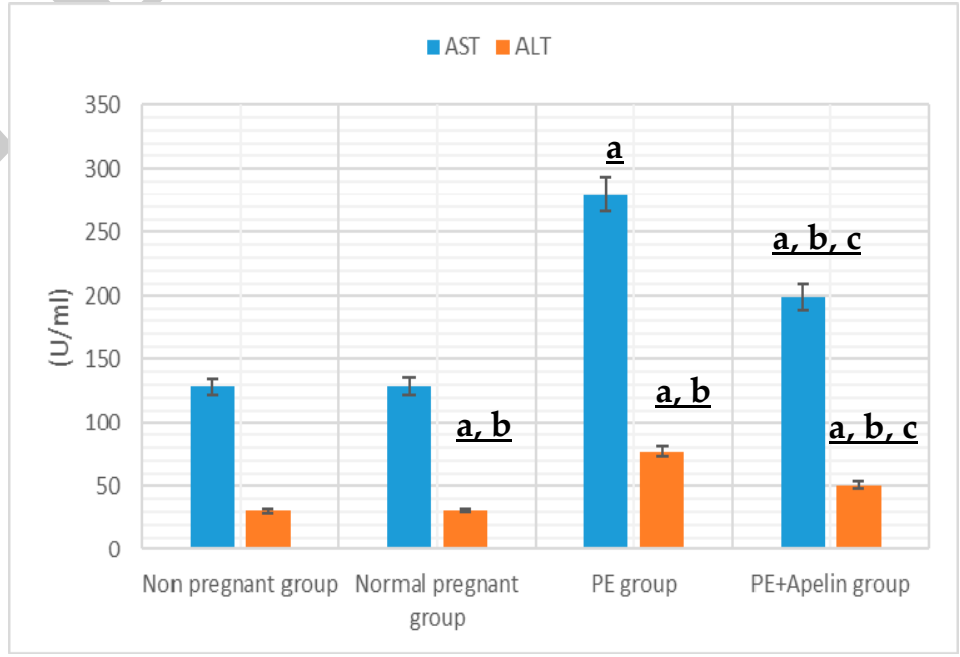

Figure 6. Serum AST and ALT in the studied groups. 
The hepatic histopathological examination conducted in this study (Figure 7) also revealed lobular inflammation and portal area fibrosis with inflammation (photo B), although these symptoms were ameliorated by apelin-13 administration in the treated preeclampsia group (photo $\mathrm{C}$ ). The histopatological variations were recorded in different treatment groups as shown in (Table 2).
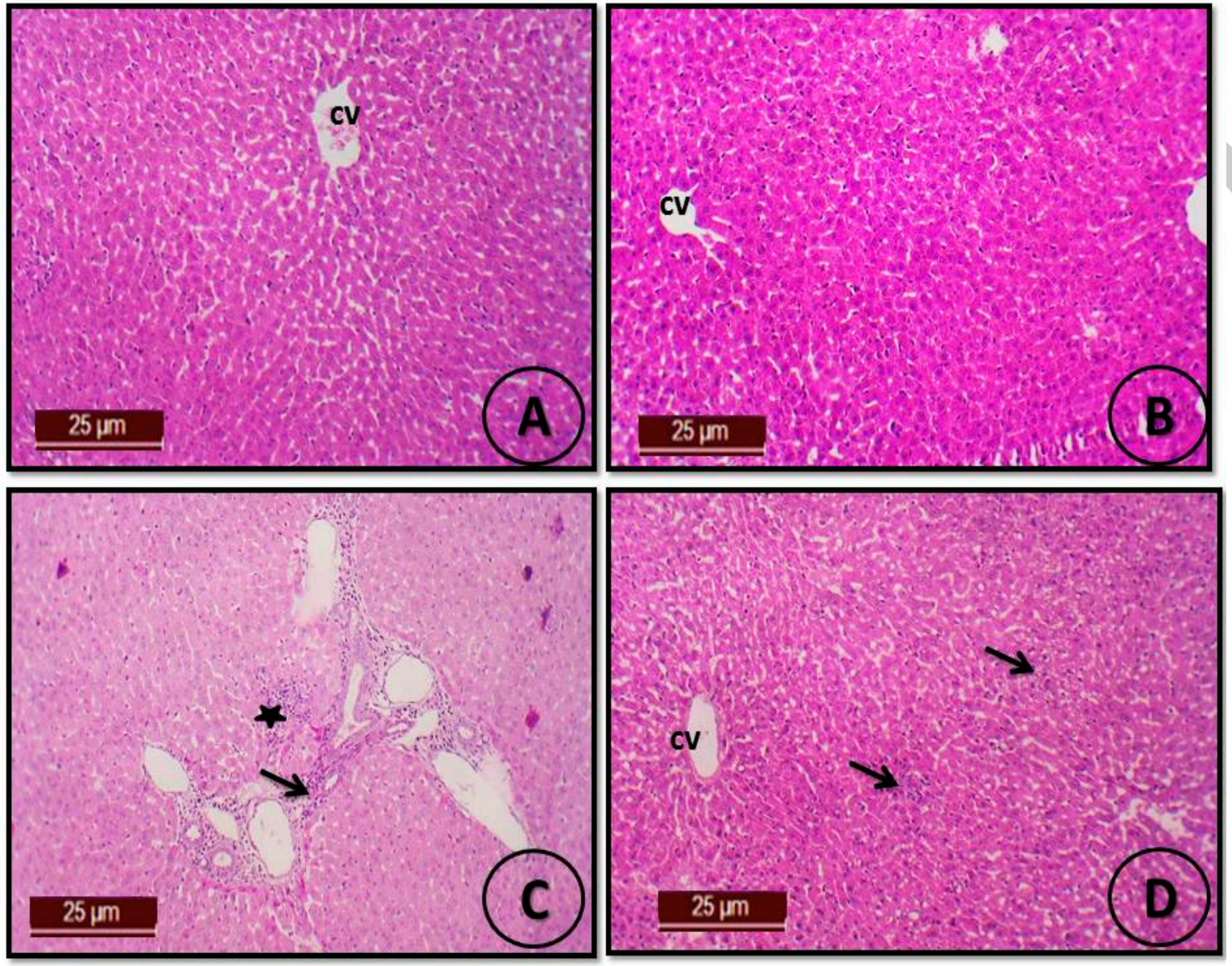

Figure 7. Cross sections of hepatic tissues showing (A) Control group (Non-pregnant group): Section in liver showing normal hepatic architecture, central vein $(\mathrm{cv})$ and cords of hepatocytes $(\mathrm{H} \& \mathrm{E} \times 200)$. (B) Normal pregnant group: Section in liver showing normal hepatic structure and normal appearance of central vein $(\mathrm{H} \& \mathrm{E} \times 200)$. (C) Preeclampsia group (PE group): Section in liver showing lobular inflammation $\left(^{*}\right)$ and portal inflammation and fibrosis (Black arrow) $(H \& E \times 200)$. (D) Preeclampsia and Apelin group: Section in liver showing nearly normal liver with only few inflammatory cells $(\mathrm{H} \& \mathrm{E} \times 200)$.

Table 2. Histopathological findings in hepatic tissues of treated groups, respectively.

\begin{tabular}{ccccc}
\hline Findings & Control Group & Normal Pregnant Group & Preeclampsia & Preeclampsia + Apelin Group \\
\hline Normal hepatic structure & ++++ & ++++ & - & -+++ \\
\hline Lobular inflammation & - & - & ++++ & -+ \\
\hline Fibrosis & - & - & ++++ & -+-+ \\
\hline Portal inflammation & - & - & ++++ & --++ \\
\hline Few inflammatory cells & - & - & ++++ & - \\
\hline
\end{tabular}

- : Absence of the change in the animals of the studied group; ++++: A change was observed in $90 \%$ the group; -+++: A change was observed in $80 \%$ the group; - - ++: A change was observed in 50\% of the group; - - + +: A change was observed in $25 \%$ of the group. 


\section{Discussion}

Preeclampsia is a potentially life-threatening condition complicating $3-5 \%$ of all pregnancies worldwide. This disorder is associated with significant rates of morbidity and mortality in both the mother and fetus (about 60,000 maternal deaths per year). Therefore, the burden of the disease rests primarily on the fetus born prematurely, who may have a low birth weight, respiratory distress syndrome, and other complications of early delivery. Additionally, after preeclampsia in pregnancy, women have increased risks of developing cardiovascular and renal disease. In addition, the diagnosis of preeclampsia remains a challenge, so this study aimed to establish a preeclampsia-like SD rat model using L-NAME and to evaluate vascular dysfunction, oxidative stress, metabolic parameters, inflammation, angiogenic markers, and apelin in this rat model and in preeclamptic rats treated with apelin in order to clarify the possible mechanism by which preeclampsia occurs and to determine the possible links among angiogenic factors and adipocytokines related to the pathophysiology of preeclampsia. In addition, we aimed to investigate the effects of apelin in a rat model of preeclampsia. For this purpose, we evaluated the following parameters: HOMA-Insulin resistance (insulin and glucose levels) and cholesterol and triglyceride concentrations.

Apelin is required for normal vascular development and has properties consistent with having roles in both normal and pathologic angiogenesis [34]. Additionally, numerous cardiovascular effects have been reported. Intravenous administration of apelin in rats was found to lower blood pressure through the release of nitric oxide [10]. Apelin has a direct activating effect on the L-arginine/eNOS/NO pathway [35]. Wang et al. [21] found that apelin treatment significantly improved the expression of eNOS in the placenta and the levels of NO and eNOS in the serum, which were all decreased in rats with PE. In the present study, treatment with apelin significantly ameliorated the preeclampsia symptoms.

In this study, preeclampsia, characterized by the development of hypertension and proteinuria, developed in L-NAME-treated rats. Preeclamptic rats showed statistically significant higher values of AST and ALT compared with healthy pregnant rats. They also showed significantly lower serum albumin levels. Dacaj et al. [36] also reported significant increases in hepatic enzymes (AST, ALT) with lower albumin levels in preeclamptic women. The hepatic histopathological examination conducted in this study also revealed lobular inflammation associated with portal area fibrosis and inflammation.

The elevated serum level of AST in preeclampsia is explained by the effect of hypoxia on the liver in cases of preeclampsia in pregnancy. The disruption of the endothelium leads to a reduction in the prostacyclin level and an increase in the thromboxane level, which causes the blood vessels of the liver to vasoconstrict, leading to the necrosis and degeneration of hepatocytes and thus increasing ALT and AST levels [36].

Some studies showed that apelin has anti-inflammatory effects by decreasing the mRNA levels of IL- 6 and TNF- $\alpha$. Additionally, it inhibits the release of reactive oxygen species and promotes the expression of antioxidative enzymes [16].

Concerning the effects of L-NAME administration and treatment with apelin on the serum levels of cholesterol and triglycerides at GD 20, the obtained results revealed that the administration of L-NAME to pregnant rats significantly increased serum cholesterol and triglyceride levels in rats with preeclampsia, while apelin treatment reversed the PE-associated elevations. These results demonstrate the beneficial effects of apelin on preeclampsia.

Moreover, during pregnancy, NO synthesis and release in endothelial cells have important roles in vascular relaxation and the regulation of vascular tension as well as contributing to elevated blood flow and fetal growth during pregnancy [37]. Chronic inhibition of NO production increases blood pressure in a volume-dependent manner [38]. The present study observed a decreased circulating NO level following treatment with L-NAME in preeclamptic rats compared with that of control ones. On the other hand, apelin-13 administration significantly reversed the decrease of serum NO levels in the treated preeclamptic rats. Wang et al. [21] also found that apelin treatment significantly improved the expression 
of eNOS in the placenta and the levels of NO and eNOS in the serum. They suggested that restoration of the eNOS/NO pathway may be involved in the ameliorative effects of apelin on preeclampsia. Antifibrotic actions of apelin through the apelin/APJ/Akt/eNOS pathway that counteract Ang II have also been reported in unilateral ureteric obstructioninduced renal fibrosis [39].

However, placental ischemia may contribute to vasoconstriction, high blood pressure, endotheliosis, and proteinuria via antiangiogenic factors and agonistic autoantibodies that bind to the AT1 receptors and increase angiotensin II sensitivity. Endothelin 1 (ET1) is a potent vasoconstrictor that has been shown experimentally to mediate hypertension, as reported in our previous paper. This is caused by sFLT1 and AT1- autoantibodies [22].

These results are in line with animal studies by Raafat and Fathy [40] and human studies by Carty et al. [41] and Khoury et al. [42], which demonstrated that the lipid levels in women with preeclampsia are higher than those in healthy pregnant women.

In a review of 22 studies, Ray et al. [43] reported that women with elevated levels of triglycerides had twice the risk of preeclampsia, and the four studies that adjusted for confounders (age, BMI and parity) indicated that the risk was four times higher than that of women with normal levels of triglycerides. It was also suggested that an assessment of triglycerides between 28 and 32 weeks could be predictive of preeclampsia. Several other investigators have reported that hypertriglyceridemia could be involved in the pathogenesis of hypertensive disorders during pregnancy [44,45].

Additionally, Rymer et al. [46] and Alahakoon et al. [47] demonstrated that all lipids and apolipoproteins are significantly elevated in pregnancy, the most prominent change being a 2.7-fold increase in triglycerides in the third trimester.

However, Siddiqui, [48] showed that there are no statistical differences in the total cholesterol, HDL, and LDL concentrations between preeclamptic women and normal pregnant women; therefore, these factors are not related to the disease. However, elevated serum triglycerides might be involved in endothelial damage leading to pre-eclampsia. Moreover, raised serum triglycerides may have value $t$ as screening markers in the early stages of pregnancy that could be associated with the later development of pre-eclampsia.

Concerning the effects of L-NAME administration and the treatment with apelin on the serum levels of insulin and glucose and HOMA-IR at GD 20, the obtained results revealed that the administration of L-NAME to pregnant rats was associated with significant increases in serum glucose and insulin levels and HOMA-IR in rats with preeclampsia, suggesting the development of insulin resistance. Of note, apelin treatment reversed the PE-associated elevations in insulin and glucose levels. These results demonstrate the beneficial effects of apelin on preeclampsia.

These results are in line with animal studies by Raafat and Fathy [40] and human studies by Masuyama et al. [49], which demonstrated that insulin resistance is associated with preeclampsia. Additionally, Thadhani et al. [50] stated that women with low levels of PlGF, a surrogate insulin resistance marker, in the first trimester have an increased risk of developing subsequent PE. These data indicate that women with preexisting alterations in insulin sensitivity have exaggerated responses to alterations in circulating angiogenic factors, including sEng, and both alterations may interact to magnify the risk for PE.

This may be due to blockage of the expression of eNOS in the placenta and the levels of NO and eNOS in the serum in PE, which causes peripheral insulin resistance, secondary to blockage of the hepatic parasympathetic reflex release of hepatic insulin sensitizing substance in response to insulin [40]. Thus, apelin helps to ameliorate these effects as it has a direct activating effect on the L-arginine/eNOS/NO pathway [35,51]. These results suggest that restoration of the eNOS/NO pathway may be involved in the ameliorative effects of apelin on preeclampsia. Additionally, oxidative stress and inflammation have been suggested to contribute to insulin resistance [52].

Of note, apelin treatment reversed the PE-associated elevations in insulin and glucose levels. These results demonstrate the beneficial effects of apelin on preeclampsia. 
Apelin helps to ameliorate these effects, as it has a direct activating effect on the Larginine/eNOS/NO pathway [51].

In conclusion, the results of the present study suggest that apelin ameliorates the pathologies of preeclampsia associated with hepatic injury. The restoration of the eNOS/NO pathway, reduction of cellular hypoxia, and inhibition of inflammation and oxidative stress may be involved in the ameliorative effect of apelin on preeclampsia.

Author Contributions: Conceptualization, R.Z.H., A.A.A.D., M.H.Z., M.S.A., S.M.M.M. and N.M.A.-B.; methodology, R.Z.H., A.A.A.D., M.S.A. and N.M.A.-B.; software, R.Z.H., A.A.A.D., M.S.A. and S.M.M.M.; validation, R.Z.H., M.H.Z., S.M.M.M. and N.M.A.-B.; formal analysis, R.Z.H., A.A.A.D., M.H.Z., S.M.M.M. and N.M.A.-B.; investigation, R.Z.H., A.A.A.D., M.H.Z., S.M.M.M. and N.M.A.-B.; resources, R.Z.H., A.A.A.D., M.H.Z., S.M.M.M. and N.M.A.-B.; data curation, R.Z.H., A.A.A.D., M.H.Z., M.S.A., S.M.M.M. and N.M.A.-B.; writing-original draft preparation, R.Z.H., A.A.A.D., M.H.Z., M.S.A. and N.M.A.-B.; writing-review and editing, R.Z.H., A.A.A.D., M.H.Z., M.S.A., S.M.M.M. and N.M.A.-B.; visualization, R.Z.H., A.A.A.D., M.S.A., S.M.M.M. and N.M.A.-B.; supervision, R.Z.H., A.A.A.D., M.H.Z. and N.M.A.-B.; project administration, R.Z.H., A.A.A.D., M.H.Z., M.S.A., S.M.M.M. and N.M.A.-B.; funding acquisition, R.Z.H., A.A.A.D., M.H.Z. and N.M.A.-B. All authors have read and agreed to the published version of the manuscript.

Funding: This study was supported by Faculty of Science and Faculty of Medicine, Zagazig University and Taif University Researchers supporting number (TURSP-2020/21), Taif University, Taif, Saudi Arabia.

Data Availability Statement: All the data available within the current paper.

Acknowledgments: To Taif University Researchers supporting number (TURSP-2020/21), Taif University, Taif, Saudi Arabia. Zoology Department and Faculty of Science, Zagazig University.

Conflicts of Interest: The authors declare that there is no competing interest.

\section{References}

1. Alrahmani, L.; Willrich, M. The Complement Alternative Pathway and Preeclampsia. Curr. Hypertens. Rep. 2018, 20, 40. [CrossRef]

2. Gürlek, B.; Yılmaz, A.; Durakoglugil, M.E.; Karakas, S.; Kazaz, I.M.; Önal, Ö.; Atıroglu, Ö.S. Evaluation of serum apelin-13 and apelin-36 concentrations in preeclamptic pregnancies. J. Obstet. Gynaecol. Res. 2020, 46, 58-65. [CrossRef]

3. De Souza Rugolo, L.M.; Bentlin, M.R.; Trindade, C.E. Preeclampsia: Effect on the Fetus and Newborn. NeoReviews 2011, 12, 198-206. [CrossRef]

4. Oyston, C.J.; Stanley, J.L.; Baker, P.N. Potential targets for the treatment of preeclampsia. Expert Opinion on Ther. Targets 2015, 19, 1517-1530. [CrossRef]

5. Bremer, L.; Schramm, C.; Tiegs, G. Immunology of hepatic diseases during pregnancy. Semin. Immunopathol. 2016, 38, 669-685. [CrossRef]

6. Malamitsi-Puchner, A.; Briana, D.D.; Boutsikou, M.; Kouskouni, E.; Hassiakos, D.; Gourgiotis, D. Perinatal circulating visfatin levels in intrauterine growth restriction. Pediatrics 2007, 119, e1314-e1318. [CrossRef] [PubMed]

7. O'Carroll, A.M.; Lolait, S.J.; Harris, L.E.; Pope, G.R. The apelin receptor APJ: Journey from an orphan to a multifaceted regulator of homeostasis. J. Endocrinol. 2013, 219, R13-R35. [CrossRef] [PubMed]

8. Boucher, J.; Masri, B.; Daviaud, D.; Gesta, S.; Guigné, C.; Mazzucotelli, A.; Castan-Laurell, I.; Tack, I.; Knibiehler, B.; Carpéné, C.; et al. Apelin, a newly identified adipokine up-regulated by insulin and obesity. Endocrinology 2005, 146, 1764-1771. [CrossRef] [PubMed]

9. Tatemoto, K.; Takayama, K.; Zou, M.X.; Kumaki, I.; Zhang, W.; Kumano, K.; Fujimiya, M. The novel peptide apelin lowers blood pressure via a nitric oxidedependent mechanism. Regul Pept. 2001, 99, 87-92. [CrossRef]

10. Kleinz, M.J.; Davenport, A.P. Emerging roles of apelin in biology and medicine. Pharm. Ther. 2005, 107, 198-211. [CrossRef]

11. Heinonen, M.V.; Purhonen, A.K.; Miettinen, P.; Pääkkönen, M.; Pirinen, E.; Alhava, E.; Akerman, K.; Herzig, K.H. Apelin, orexin-A and leptin plasma levels in morbid obesity and effect of gastric banding. Regul. Pept. 2005, 130, 7-13. [CrossRef]

12. Kasai, A.; Shintani, N.; Oda, M.; Kakuda, M. Apelin is a novel angiogenic factor in retinal endothelial cells. Biochem. Biophys. Res. Commun. 2004, 325, 395-400. [CrossRef]

13. Kunduzova, O.; Alet, N.; Delesque-Touchard, N.; Millet, L.; Castan-Laurell, I.; Muller, C.; Dray, C.; Schaeffer, P.; Herault, J.P.; Savi, P.; et al. Apelin/APJ signaling system: A potential link between adipose tissue and endothelial angiogenic processes. FASEB J. 2008, 22, 4146-4153. [CrossRef] [PubMed]

14. Sörhede Winzell, M.; Magnusson, C.; Ahrén, B. The apj receptor is expressed in pancreatic islets and its ligand, apelin, inhibits insulin secretion in mice. Regul. Pept. 2005, 131, 12-17. [CrossRef] [PubMed] 
15. Higuchi, K.; Masaki, T.; Gotoh, K.; Chiba, S.; Katsuragi, I.; Tanaka, K.; Kakuma, T.; Yoshimatsu, H. Apelin, an APJ receptor ligand, regulates body adiposity and favors the messenger ribonucleic acid expression of uncoupling proteins in mice. Endocrinology 2007, 148, 2690-2697. [CrossRef] [PubMed]

16. Soliman, M.; Arafah, M. Apelin protect against multiple organ injury following hemorrhagic shock and decrease the inflammatory response. Int. J. Appl. Basic Med. Res. 2015, 5, 195-199. [CrossRef] [PubMed]

17. Than, A.; Zhang, X.; Leow, M.K.S.; Poh, C.L.; Chong, S.K.; Chen, P. Apelin attenuates oxidative stress in human adipocytes. J. Biol. Chem. 2014, 289, 3763-3774. [CrossRef]

18. Zhou, H.; Yang, R.; Wang, W.; Xu, F.; Xi, Y.; Brown, R.; Zhang, H.; Shi, L.; Zhu, D.; Gong, D. Fc-apelin fusion protein attenuates lipopolysaccharide-induced liver injury in mice. Sci. Rep. 2018, 8, 11428. [CrossRef]

19. Abdul Aziz, S.H.; John, C.M.; Mohamed Yusof, N.I.; Massita, N.; Rajesh, R.; Adam, A.; Fazlin, M.F. Animal Model of Gestational Diabetes Mellitus with Pathophysiological Resemblance to the Human Condition Induced by Multiple Factors (Nutritional, Pharmacological, and Stress) in Rats. Biomed. Res. Int. 2016, 2016, 9704607. [CrossRef]

20. Shu, W.; Li, H.; Gong, H.; Zhang, M.; Niu, X.; Ma, Y.; Zhang, X.; Cai, W.; Yang, G.; Wei, M.; et al. Evaluation of blood vessel injury, oxidative stress and circulating inflammatory factors in an L-NAME-induced preeclampsia-like rat model. Exp. Ther. Med. 2018, 16, 585-594. [CrossRef] [PubMed]

21. Wang, C.; Liu, X.; Kong, D.; Qin, X.; Li, Y.; Teng, X.; Huang, X. Apelin as a novel drug for treating preeclampsia. Exp. Ther. Med. 2017, 14, 5917-5923. [CrossRef]

22. Abubakar, M.G.; Ukwuani, A.N.; Mande, U.U. Antihypertensive activity of Hibiscus Sabdariffa aqueous calyx extract in Albino rats. Sky J. Biochem. Res. 2015, 4, 16-20.

23. Temple, R.C.; Clark, P.M.; Hales, C.N. Measurement of insulin secretion in type II diabetes: Problems and pitfalls. Diabet. Med. 1992, 9, 503-512. [CrossRef] [PubMed]

24. Tietz, N.W.; Cook, T.; McNiven, M.A. Clinical Guide to Laboratory Tests; W.B. Saunders: Philadelphia, PA, USA, $1995 ;$ pp. 509-512.

25. Sun, G.; Bishop, J.; Khallili, S.; Vasdev, S.; Gill, V.; Pace, D. Serum visfatin concentrations are positively correlated with serum triacylglycerols and downregulated by overfeeding in healthy young men. Am. J. Clin. Nutr. 2007, 85, 399-404. [CrossRef] [PubMed]

26. Varley, H.; Richmond, S. Determination of Total, Free and Ester Cholesterol Using Reaction with Ferric Chloride and Sulfuric Acid. In Practical Clinical Biochemistry, 4th ed.; Jaypee Brothers Medical Pub: New Delhi, India, 1976; p. 313.

27. Fossati, P.; Prencipe, L. Serum triglycerides determined colorimetrically with an enzyme that produces hydrogen peroxide. Ann. Clin. Biochem. 1982, 28, 2077-2080. [CrossRef]

28. Schirmeister, J.; Willmann, H.; Kieffr, H. Plasma Creatinine as Rough Indicator DER Of Renal Function. Dtsch. Med. Wochenschr. 1964, 89, 1018-1023. [CrossRef] [PubMed]

29. Ignarro, L.J.; Fukuto, J.M.; Griscavage, J.M.; Rogers, N.E.; Byrns, R.E. Oxidation of nitric oxide in aqueous solution to nitrite but not nitrate: Comparison with enzymatically formed nitric oxide from Larginine. Proc. Natl. Acad. Sci. USA 1993, 90, 8103-8107. [CrossRef]

30. Zhao, Y.; Yang, X. Lu, W.; Liao, H.; Liao, F. Uricase based methods for determination of uric acid in serum. Microchim. Acta. 2009, 164, 1-6. [CrossRef]

31. Suzuki, K.; Ota, H.; Sasagawa, S.; Sakatani, T.; Fujikura, T. Assay method for myeloperoxidase in human polymorphonuclear leukocytes. Anal. Biochem. 1983, 132, 345-352. [CrossRef]

32. Litwack, G.; Bothwell, J.W.; Williams, J.N.; Elvehjem, C.A. A colorimetric assay for xanthine oxide in rat liver homogenates. J. Biol. Chem. 1953, 200, 303-310. [CrossRef]

33. Drury, R.; Wallington, E. Preparation and Fixation of Tissues; Oxford University Press: Oxford, UK, 1980; pp. 41-54.

34. Tatemoto, K.; Hosoya, M.; Habata, Y.; Fujii, R.; Kakegawa, T.; Zou, M.X.; Kawamata, Y.; Fukusumi, S.; Hinuma, S.; Kitada, C.; et al. Isolation and characterization of a novel endogenous peptide ligand for the human APJ receptor. Biochem. Biophys. Res. Commun. 1998, 251, 471-476. [CrossRef]

35. Busch, R.; Strohbach, A.; Pennewitz, M.; Lorenz, F.; Bahls, M.; Busch, M.C.; Felix, S.B. Regulation of the endothelial apelin/APJ system by hemodynamic fluid flow. Cell Signal. 2015, 27, 1286-1296. [CrossRef] [PubMed]

36. Dacaj, R.; Izetbegovic, S.; Stojkanovic, G.; Dreshaj, S. Elevated Liver Enzymes in Cases of Preeclampsia and Intrauterine Growth Restriction. Med. Arch. 2016, 70, 44-47. [CrossRef]

37. Eckman, D.M.; Gupta, R.; Rosenfeld, C.R.; Morgan, T.M.; Charles, S.M.; Mertz, H.; Moore, L.G. Pregnancy increases myometrial artery myogenic tone via NOS- or COX-independent mechanisms. Am. J. Physiol Regul. Integr. Comp. Physiol. 2012, 303, R368-R375. [CrossRef]

38. Vechoropoulos, M.; Ish-Shalom, M.; Shaklai, S.; Sack, J.; Stern, N.; Tordjman, K.M. The proatherogenic effect of chronic nitric oxide synthesis inhibition in ApoE-Null mice is dependent on the presence of PPAR $\alpha$. PPAR Res. 2014, 2014, 124583. [CrossRef]

39. Nishida, M.; Okumura, Y.; Oka, T.; Toiyama, K.; Ozawa, S.; Itoi, T.; Hamaoka, K. The role of apelin on the alleviative effect of Angiotensin receptor blocker in unilateral ureteral obstruction-induced renal fibrosis. Nephron. Extra. 2012, 2, 39-47. [CrossRef]

40. Raafat, N.A.; Fathy, M.A. Serum Adropin Levels in a Preeclampsia Like L-Name Rat Model Treated with Sildenafil Citrate. Med. J. Cairo Univ. 2018, 86, 3753-3765.

41. Carty, D.M.; Delles, C.; Dominiczak, A.F. Novel biomarkers for predicting preeclampsia. Trends Cardiovasc. Med. 2008, 18, 186-194. [CrossRef] 
42. Khoury, J.; Amundsen, A.L.; Tonstad, S.; Henriksen, T.; Ose, L.; Retterstøl, K.; Iversen, P.O. Evidence for impaired physiological decrease in the uteroplacental vascular resistance in pregnant women with familial hypercholesterolemia. Acta Obste Gynecol. Scand. 2009, 88, 222-226. [CrossRef] [PubMed]

43. Ray, J.G.; Diamond, P.; Singh, G.; Bell, C.M. Brief overview of maternal triglycerides as a risk factor for pre-eclampsia. BJOG 2006, 113, 379-386. [CrossRef] [PubMed]

44. Ziaei, S.; Bonab, K.M.; Kazemnejad, A. Serum lipid levels at 28-32 weeks gestation and hypertensive disorders. Hypertens Pregnancy 2006, 25, 3-10. [CrossRef]

45. Gofman, J.; Delalla, O.; Glazier, F.; Freeman, N.K. The serum lipoprotein transport system in health, metabolic disorders, atherosclerosis and coronary heart disease. J. Clin. Lipidol. 2007, 1, 104-141. [CrossRef]

46. Rymer, J.; Constable, S.; Lumb, P.; Crook, M. Serum lipoprotein (a) and apolipoproteins during pregnancy and postpartum in normal women. J. Obstet Gynaecol. 2002, 22, 256-259. [CrossRef] [PubMed]

47. Alahakoon, T.I.; Medbury, H.J.; Williams, H.; Lee, V.W. Lipid profiling in maternal and fetal circulations in preeclampsia and fetal growth restriction-a prospective case control observational study. BMC Pregnancy Childbirth 2020, 20, 61. [CrossRef] [PubMed]

48. Siddiqui, I.A. Maternal Serum Lipids in Women with Pre-eclampsia. Ann. Med. Health Sci. Res. 2014, 4, 638-641. [CrossRef]

49. Masuyama, H.; Suwaki, N.; Nakatsukasa, H.; Masumoto, A.; Tateishi, Y.; Hiramatrsu, Y. Circulating angiogenic factors in preeclampsia, gestational proteinuria, and preeclampsia superimposed on chronic glomerulonephritis. Am. J. Obstet Gynecol. 2006, 194, 551-556. [CrossRef] [PubMed]

50. Thadhani, R.; Ecker, J.; Mutter, W.; Wolf, M.; Smirnakis, K.; Sukhatme, V.; Levine, R.; Karumanchi, S. Insulin resistance and alterations in angiogenesis. Hypertension 2004, 43, 988-992. [CrossRef]

51. Jia, Y.X.; Lu, Z.F.; Zhang, J.; Pan, C.S.; Yang, J.H.; Zhao, J.; Yu, F.; Duan, X.; Tang, C.S.; Qi, Y.F. Apelin activates L-arginine/nitric oxide synthase/nitric oxide pathway in rat aortas. Peptides 2007, 28, 2023-2029. [CrossRef]

52. Gopaul, N.; Manraj, M.; Hébé, A.; Yan, S.; Johnston, A.; Carrier, M.; Anggård, E. Oxidative stress could precede endothelial dysfuncti on and insulin resistance in Indian Mauritians with impaired glucose metabolism. Diabetologia 2001, 44, 706-712. [CrossRef] 